\title{
Sistem Informasi Pencarian Lokasi Donor Darah PMI Kota Bandung Berbasis Web
}

\section{Blood Donor Location Information System of Web-Based in PMI Bandung}

\author{
S Nurhayati ${ }^{1 *}$, R H Nugraha ${ }^{2}$ \\ 1,2) Program Studi Sistem Komputer, Fakultas Teknik dan Ilmu Komputer, Universitas Komputer Indonesia \\ Jl. Dipati Ukur No. 112 - 116, Bandung, Indonesia 40132 \\ e-mail: sri.nurhayati@email.unikom.ac.id
}

\begin{abstract}
The purpose of this study is to create an information system that can provide information about the nearest blood donor location and route, and assist the Indonesian Red Cross (PMI) in providing blood donor location information, blood donor schedules and the process of receiving requests for donor activities. At present information about the PMI Bandung blood donor schedule is disseminated through social media, but information only shows the address, while there are some donors who do not know the location and route to that location. In addition, based on the results of interviews with PMI, demand management for blood donation activities still uses conventional methods, making it difficult for officers to request and schedule blood donor activities. Making an application in this study using Google Maps API that can display the location of blood donor activities, find the nearest location using the Location Based Service (LBS) method, and to design a system using a structured approach. Based on the results of the tests conducted, it shows that the system functions have been running as expected, and user responses indicate that this application has fulfilled the purpose of making the application.
\end{abstract}

Keywords - Information Systems, Location Based Services (LBS), Google Maps API

\begin{abstract}
ABSTRAK - Tujuan dari penelitian ini adalah untuk membuat sistem informasi yang dapat memberikan informasi tentang lokasi donor darah terdekat dan rutenya, dan membantu Palang Merah Indonesia (PMI) dalam memberikan informasi lokasi donor darah, jadwal donor darah dan proses penerimaan permintaan untuk kegiatan donor. Saat ini informasi tentang jadwal donor darah PMI Bandung disebarluaskan melalui media sosial, tetapi informasi hanya menunjukkan alamat, sementara ada beberapa donor yang tidak tahu lokasi dan rute ke lokasi itu. Selain itu, berdasarkan hasil wawancara dengan PMI, manajemen permintaan untuk kegiatan donor darah masih menggunakan metode konvensional, sehingga sulit bagi petugas untuk meminta dan menjadwalkan kegiatan donor darah. Pembuatan aplikasi dalam penelitian ini menggunakan Google Maps API yang dapat menampilkan lokasi kegiatan donor darah, menemukan lokasi terdekat menggunakan metode Location Based Service (LBS), dan menggunakan pendekatan terstruktur. Berdasarkan hasil pengujian yang dilakukan, itu menunjukkan bahwa fungsi sistem telah berjalan seperti yang diharapkan, dan tanggapan pengguna menunjukkan bahwa aplikasi ini telah memenuhi tujuan pembuatan aplikasi.
\end{abstract}

Kata Kunci - Sistem Informasi, Location Based Service (LBS), Google Maps API

\section{Pendahuluan}

Donor darah merupakan kegiatan pengambilan darah dari sesorang yang dilakukkan secara sukarela. Dari hasil donor darah tersebut, tersimpan di Palang Merah Indonesia dan akan diberikan kepada orang yang membutuhkan transfusi darah. Beberapa manfaat yang didapat dari donor darah adalah dapat menurunkan kadar profil lipid darah sehingga risiko penyakit kardiovaskuler dapat diminimalkan [1], [2].

Saat ini PMI kota Bandung, untuk proses terkait donor darah, instansi yang akan melakukkan kegiatan donor darah harus mendatangi PMI untuk proses permintaan penerimaan kegiatan donor darah masih, hal ini tentunya tidak efektif dan efisien. Banyak para pendonor yang ingin melakukkan donor darah tetapi informasi masih belum lengkap. 
informasi tentang jadwal donor darah PMI Bandung disebarluaskan melalui media sosial, tetapi informasi hanya menunjukkan alamat, sementara ada beberapa donor yang tidak tahu lokasi dan rute ke lokasi itu.

Beberapa penelitian yang dijadikan referensi untuk penelitian ini adalah penelitian yang berjudul Rancang Bangun Sistem Informasi Manajemen Pendonoran Darah Pada Udd PMI Kabupaten Pacitan [4], serta penelitian denan judul Rancang Bangun Sistem Informasi Donor Darah Berbasis Web (Studi Kasus: Unit Kegiatan Mahasiswa Korps Sukarela Universitas Mulawarman) [5], dari dua penelitian ini sistem sudah memberikan informasi tentang data pendonor darah, tetapi belum menampilkan lokasi dan rute menuju tempat donor darah. Selain dua penelitian tersebut, ada penelitian yang berjudul Rancang Bangun Aplikasi Donor Darah Berbasis Mobile di PMI Kabupaten Bandung [6], pada penelitian ini aplikasi sudah dapat menunjukkan lokasi dan rute tetapi belum memberikan rute yang terdekat dengan posisi pendonor, dan belum dilengkapi dengan proses permintaan kegiatan donor darah dari instansi.

Dari permasalahan tersebut maka akan dibuat sebuah system informasi lokasi donor darah berbasis web di PMI kota bandung yang dapat dapat memberikan informasi tentang lokasi donor darah terdekat dan rutenya, dan membantu PMI dalam memberikan informasi lokasi donor darah, jadwal donor darah dan proses penerimaan permintaan untuk kegiatan donor.

\section{METODE DAN BAHAN}

\subsection{Model Pengembangan Perangkat Lunak}

Model yang digunakan untuk pengembangan perangkat lunak pada penelitian ini menggunakan model waterfall. Model ini bersifat bersifat linear, di mulai dari tahap perencanaan perangkat lunak sampai pada tahap akhir yaitu pemeliharaan perangkat lunak [7]. Adapun tahapan pada metode ini adalah terdiri dari analisis, design, coding, testing, dan implementasi, tahapan model waterfall.

\subsection{Analisis Pencarian lokasi terdekat}

Peta lokasi untuk kegiatan donor darah di ambil dari Google Map. Google Maps merupakan layanan yang di sediakan oleh Google secara gratis untuk aplikasi peta online [8]. Sedangkan untuk mengintegrasikannya ke dalam website menggunakan Googel Map API.

Metode yang digunakan untuk pencarian lokasi donor darah terdekat menggunakan metode Location Based Service (LBS). Metode LBS berfungsi untuk memberikan suatu layanan berdasarkan lokasi dari pengguna, dalam kasus ini yaitu memberikan layanan informasi lokasi kegiatan donor darah yang terdekat dengan lokasi user. Tahap pertama untuk mencari lokasi donor darah terdekat yaitu mencari lokasi dari pengguna, setelah lokasi pengguna diketahui, maka dilakukan perhitungan jarak dari lokasi pengguna ke tiap lokasi kegiatan donor darah dengan menggunakan service dari Google Maps API,

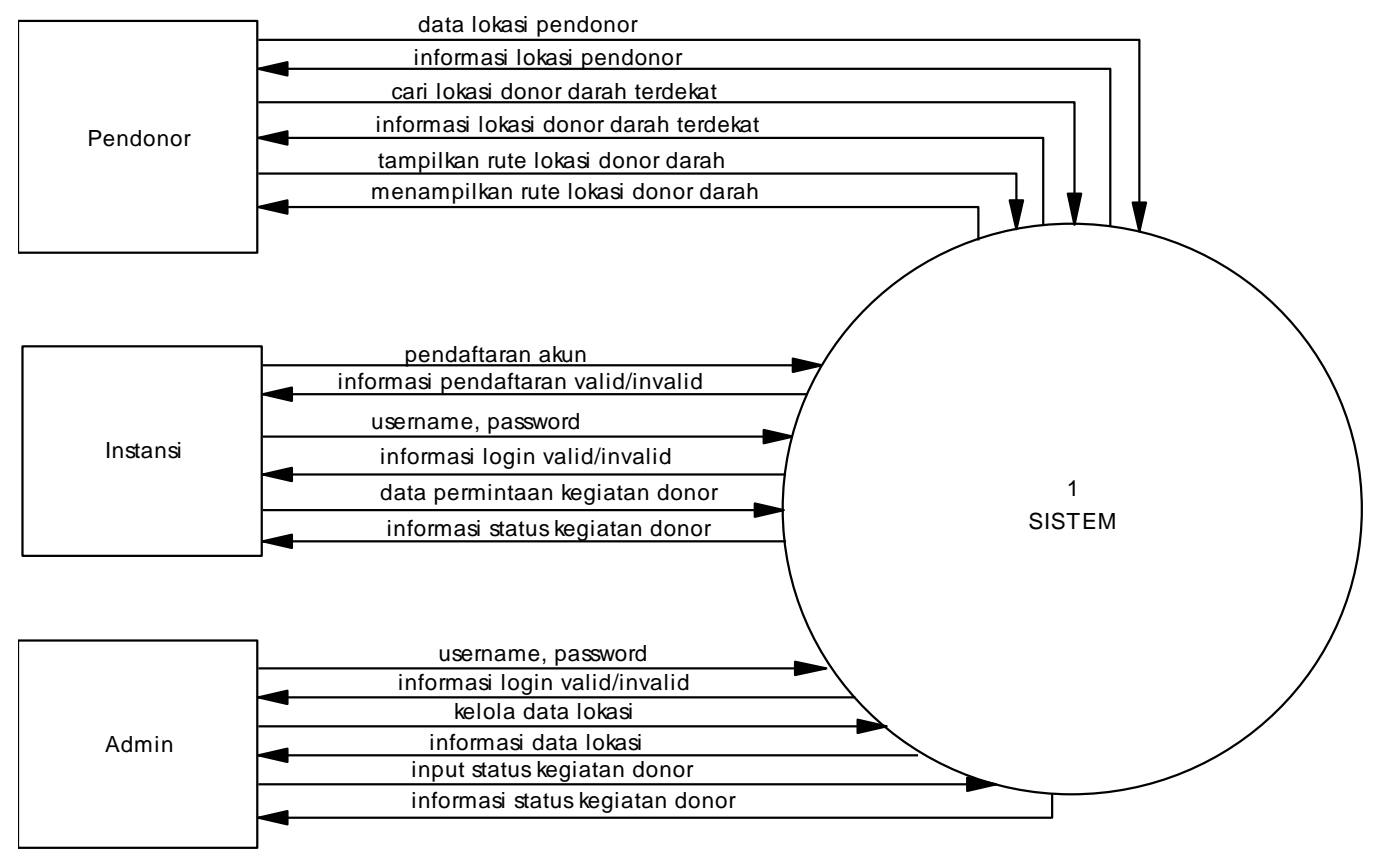

Gambar 1. Diagram Konteks 


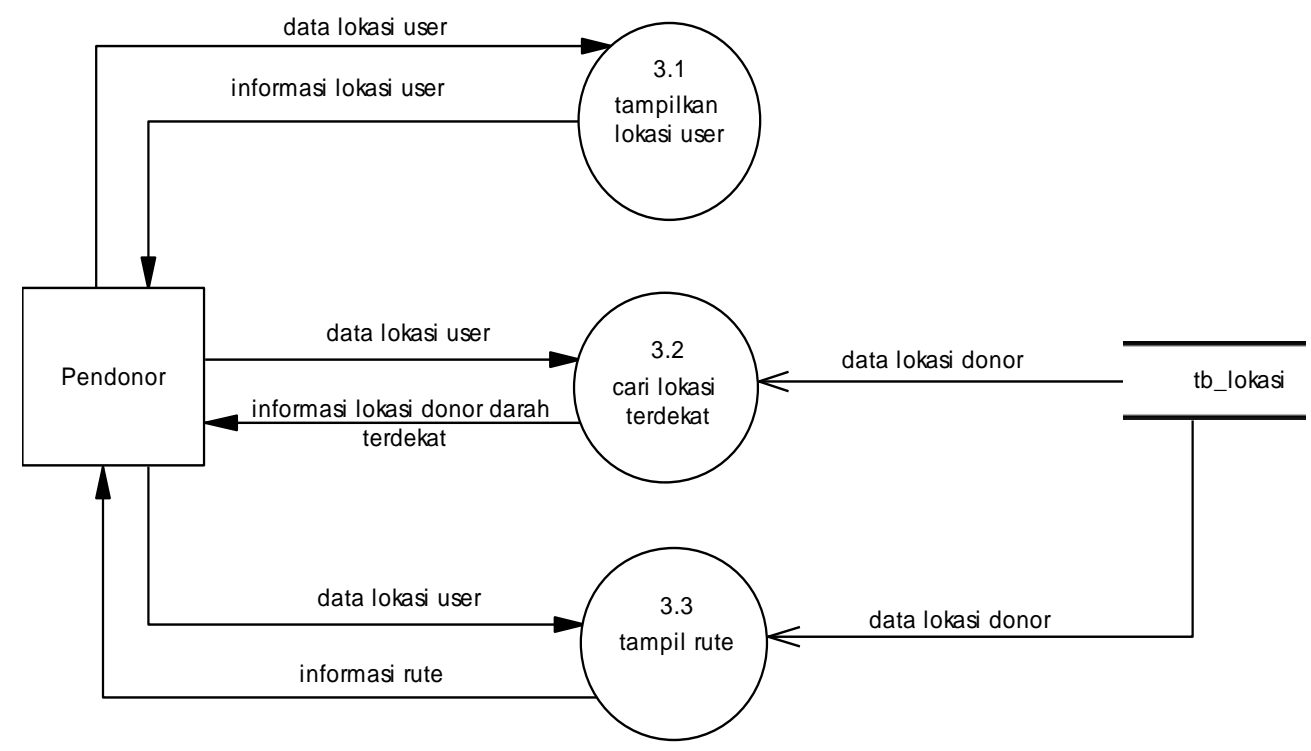

Gambar 2. Level 2 proses 3

hasil dari perhitungan tersebut adalah nilai jarak dalam satuan kilometer $(\mathrm{Km})$.

Berikut merupakan contoh kasus hasil perhitungan jarak, dapat dilihat pada Tabel 1 berikut.

Tabel 1. Hasil Perhitungan Jarak

\begin{tabular}{|c|c|c|}
\hline $\begin{array}{l}\text { Lokasi } \\
\text { Pendonor }\end{array}$ & $\begin{array}{c}\text { Lokasi Kegiatan Donor } \\
\text { Darah }\end{array}$ & $\begin{array}{l}\text { Jarak } \\
\text { (Km) }\end{array}$ \\
\hline \multirow{6}{*}{$\begin{array}{l}\text { Simpang } \\
\text { Dago }\end{array}$} & Teknologi & 8 \\
\hline & Nasional (ITENAS) & \\
\hline & $\begin{array}{l}\text { Universitas } \\
\text { (UNPAS) }\end{array}$ & 10 \\
\hline & Universitas & 1 \\
\hline & Indonesia (UNIKOM) & \\
\hline & $\begin{array}{l}\text { Universitas Widyatama } \\
\text { (WIDYATAMA) }\end{array}$ & 6 \\
\hline
\end{tabular}

Setelah nilai jarak diketahui, maka akan dicari nilai jarak yang paling kecil menggunakan Algoritma Sequential search. Algoritma ini membandingkan tiap nilai jarak sehingga diketahui nilai jarak yang paling kecil.

\subsection{Analisis Kebutuhan Sistem}

Analisis dari system pada penelitian ini menggunakan pendekatan terstruktur. Analisis ini difokuskan pada aliran data dan proses bisnis, dan rangkaian dari proses digambarkan dalam bentuk diagram alir data (data flow diagram). Pada diagram alir data akan tergambarkan input, output dan file yang digunakan [9].

Kebutuhan fungsional dari perangkat lunak yang akan dibangun dijelaskan sebagai berikut: a. Instansi membuat permintaan kegiatan donor darah.

b. Admin melakukan pengelolaan data lokasi, jadwal, dan menentukan status permintaan kegiatan donor darah dari setiap instansi.

c. Pendonor melihat informasi lokasi kegiatan donor darah terdekat beserta rutenya.

Berdasarkan kebutuhan fungsional, proses dari system dimodelkan menggunakan data flow diagram (DFD). Gambar 1 merupakan diagam konteks dari system. Dari gambar 1 diturunkan menjadi diagram level 1 terdiri dari 9 proses, proses tersebut dapat di lihat pada tabel 2.

Tabel 2. Kebutuhan proses

\begin{tabular}{c|l}
\hline No Proses & \multicolumn{1}{c}{ Nama Proses } \\
\hline Proses 1 & Login \\
Proses 2 & Melihat lokasi donor darah \\
Proses 3 & Mencari lokasi donor terdekat \\
Proses 4 & Melihat jadwal \\
Proses 5 & Mendaftar akun \\
Proses 6 & Permintaan kegiatan donor darah \\
Proses 7 & Periksa ketersediaan jadwal \\
Proses 8 & Kelola data lokasi \\
Proses 9 & $\begin{array}{l}\text { Kelola status permintaan kegiatan } \\
\text { donor darah }\end{array}$ \\
\hline
\end{tabular}

Sesuai dengan perannya, untuk masuk ke system, pengguna instansi dan admin harus melakukkan proses 1 terlebih dahulu yaitu login. 


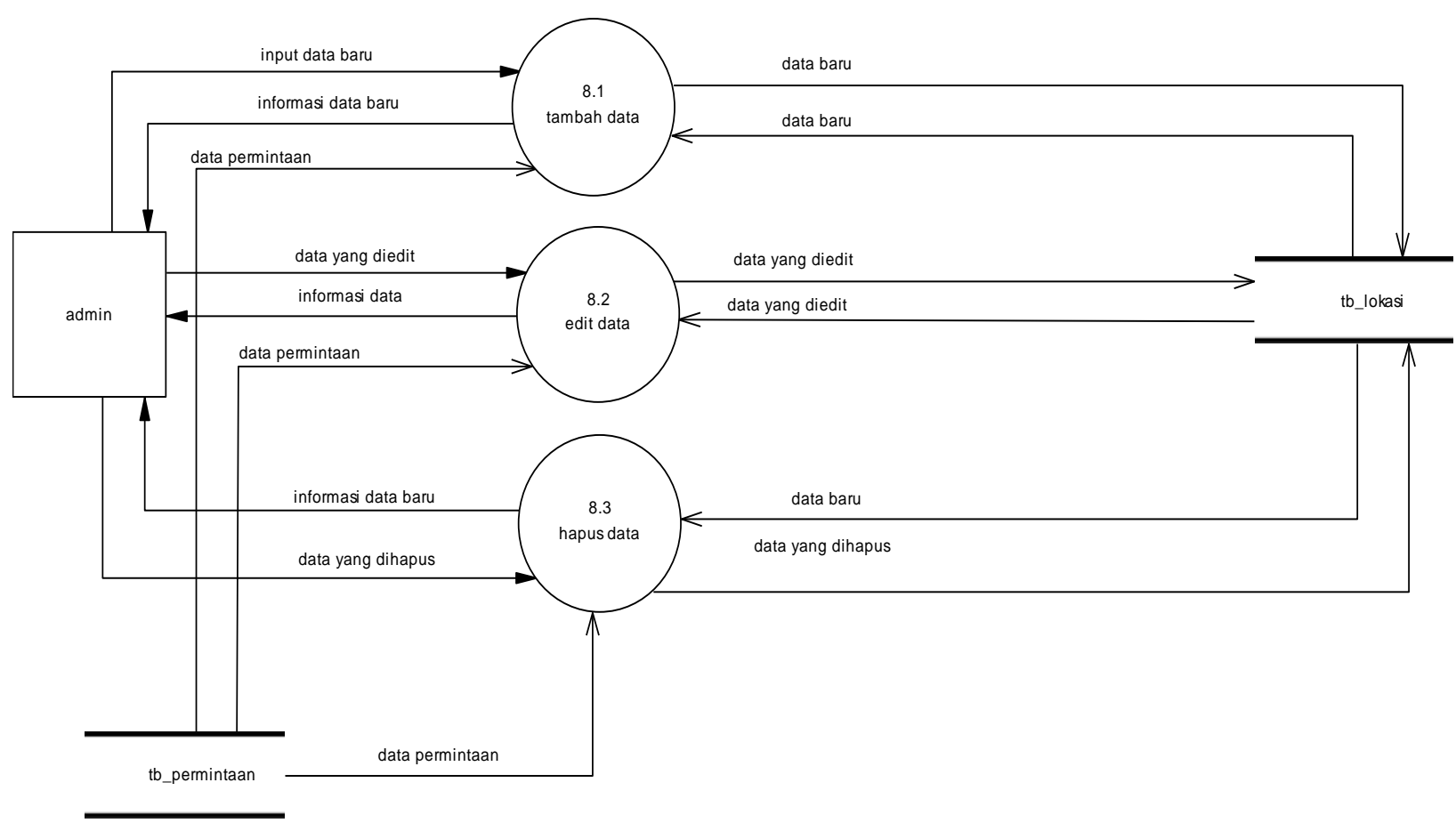

Gambar 3. Level 2 proses 8

Proses 2, 3, dan 4 merupakan proses yang dilakukan oleh pendonor. Pada proses 2 melihat lokasi donor dara, pengguna dapat di peta kegiatan donor darah ada di mana saja beserta denan jadwal pelaksanaannya. Proses 3 mencari lokasi donor terdekat merupakan prosen yang diturunkan menjadi level 2, level 2 dari proses tersebut dapat dilihat pada gambar 3. Pada proses ini, pendonor dapat mencari lokasi terdekat kegiatan donor darah beserta informasi rute untuk sampai ke tempat kegiatan donor darah.

Proses 5, 6, dan 7 merupakan proses yang dilakukan oleh instansi, sedangkan proses 8 dan 9 merupakan proses yang dilakukan oleh admin. Proses 5 mendaftar akun adalah proses yang dilakukkan oleh instansi untuk endaftar sebagai tempat pelaksanaan kegiatan donor darah. Proses 6 permintaan kegiatan donor darah adalah proses yang dilakukkan oleh instansi untuk melakukkan permintaan kegiatan donor darah ke PMI. Sedangkan proses 7 adalaha proses untuk melihat ketersediaan jadwal kegiatan donor darah yang ada di PMI.

Proses 8 dan 9 adalah proses yang dilakukkan oleh admin PMI, dimana proses 8 adalah proses untuk kelolal data lokasi kegiatan donor darah yang ada di adakan oleh PMI dan instansi tertentu, dan proses 9 adalah proses untuk persetujuan permintaan kegiatan donor datrah dari instansi tertentu. Proses 8 diturunlan menjadi level 2, dapat dilihat pada gambar 3 .
Berikut adalah beberapa spesifikasi proses dari system yang dibuta terlihat pada tabel 3 ditampilkan spesifikasi proses 3.2 untuk mencari lokasi donor darah terdekat, dan tabel 4 menampilkan spesifikasi proses 6 permintaan kegiatan donor darah, dan tabel 5 spesifikasi proses 9 kelola status permintaan kegiatan donor darah. Model basis data yang digunakan pada perancangan system ini menggunakan relasi diagram (Entity Relationship Diagram). Terdapat 4 entitas dalam system yang dibangun, relasi diagram dari system dapat dilihat pada gambar 4 .

Tabel 3. Spesifikasi proses mencari lokasi donor darah terdekat

\begin{tabular}{|c|c|}
\hline Nomor Proses & 3.2 \\
\hline Nama Proses & Mencari Lokasi donor darah terdekat \\
\hline Masukan & Data lokasi user \\
\hline Keluaran & $\begin{array}{l}\text { Informasi lokasi donor darah terdekat dan } \\
\text { jarak }\end{array}$ \\
\hline Logika Proses & $\begin{array}{l}\text { a.Pendonor akan mengirimkan koordinat } \\
\text { lokasi ke system } \\
\text { b.System akan menghitung jarak dari tiap } \\
\text { titik lokasi donor darah } \\
\text { c. System menampilkan lokasi kegiatan } \\
\text { donor darah terdekat dan jaraknya }\end{array}$ \\
\hline
\end{tabular}




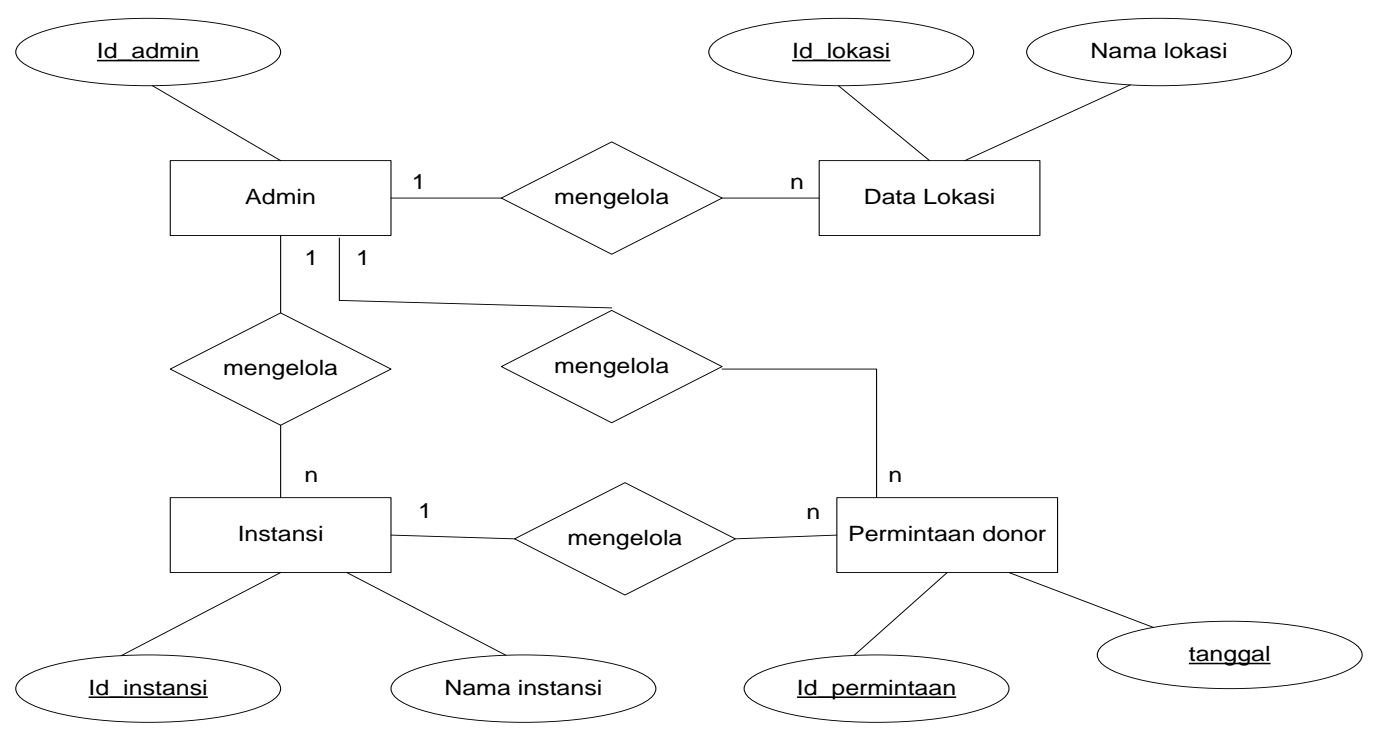

Gambar 4. ERD Sistem

Tabel 4. Spesifikasi proses Permintaan kegiatan donor darah

\begin{tabular}{ll}
\hline Nomor Proses & 6 \\
\hline Nama Proses & Permintaan kegiatan donor darah \\
\hline Masukan & Nama_instansi, alamat, tanggal \\
\hline Keluaran & Status kegiatan donor darah \\
\hline Logika Proses & a. Instansi mengisi form data \\
& permintaan kegiatan donor darah \\
& b. System akan menyimpan \\
& permintaan kegiatan donor darah \\
\hline
\end{tabular}

Tabel 5. Spesifikasi proses mencari lokasi donor darah terdekat

\begin{tabular}{|c|c|}
\hline Nomor Proses & 9 \\
\hline Nama Proses & $\begin{array}{l}\text { Kelola status permintaan kegiatan donor } \\
\text { darah }\end{array}$ \\
\hline Masukan & Status kegiatan \\
\hline Keluaran & $\begin{array}{l}\text { Informasi status permintaan kegiatan } \\
\text { donor darah }\end{array}$ \\
\hline Logika Proses & $\begin{array}{l}\text { a. System menampilkan data } \\
\text { permintaan kegiatan donor darah } \\
\text { b. Admin memilih data permintaan } \\
\text { kegiatan donor darah } \\
\text { c. Admin menentukan status kegiatan } \\
\text { donor darah apakah diterima atau } \\
\text { ganti judul }\end{array}$ \\
\hline & $\begin{array}{l}\text { d. System akan menyimpan status } \\
\text { permintaan kegiatan donor darah ke } \\
\text { dalam database }\end{array}$ \\
\hline
\end{tabular}

\subsection{Perancangan Sistem}

Komponen yang penting dalam pengembangna system salah satunya adalah rancangan system. Rancangan ini digunakan sebagai pedoman dalam membangun sebuah system.
Perancangan antarmuka dari system terbagi menjadi perancangan antar muka pendonor, instansi, dan admin PMI. Beberapa contoh rancangan antarmuka dapat dilihat pada gambar 5, 6 dan 7 .

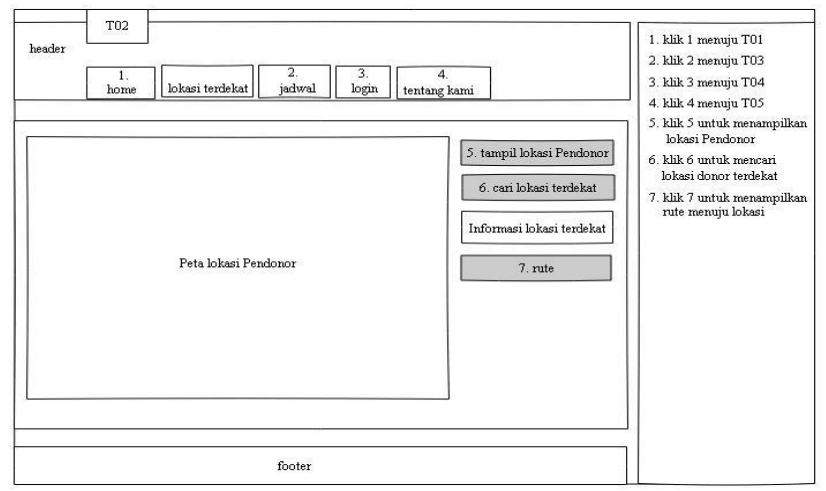

Gambar 5 Rancangan Antarmuka Pencarian Lokasi Terdekat untuk pendonor

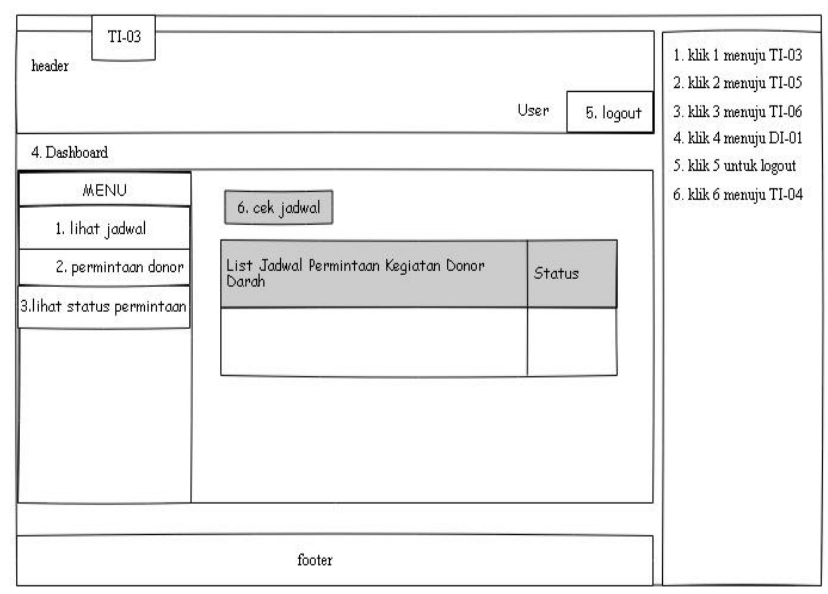

Gambar 6. Rancangan Antarmuka Jadwal Permintaan untuk instansi 


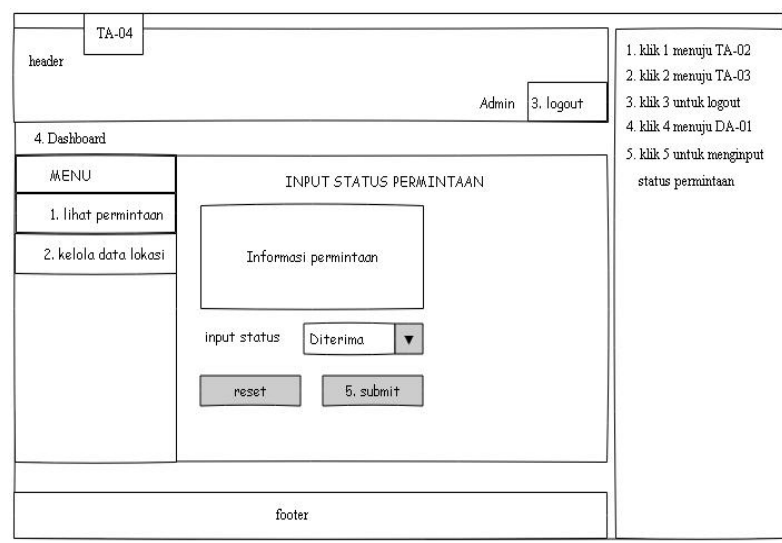

Gambar 7. Perancangan Antarmuka Input Status Permintaan

\section{HaSil dan PeMbahasan}

Hasil dari analisis dan perancangan sistem terbagi menjadi halaman pendonor, instansi, dan admin PMI. Beberapa contoh implenetasi sistem untuk pendonor dapat dilihat pada gambar 8, 9, dan 10.

Pada Gambar 8, menampilkan rute untuk menuju ke lokasi kegiatan donor darah yang terdekat dengan pendonor.

Gambar 9, merupakan halaman yang digunakan untuk permintaan kegiatan donor darah. Menu permintaan donor berfungsi untuk mengajukan permintaan kegiatan donor kepada pihak PMI Kota Bandung. Instansi harus mengisi form yang kosong, setelah itu menekan tombol Submit. Jika proses tersebut berhasil disimpan maka aplikasi akan menampilkan pesan "Permintaan berhasil".

Menu input status permintaan kegiatan donor darah berfungsi untuk memberikan status apakah permintaan tersebut diterima, ataupun ditolak, dapat dilihat pada Gambar 10.

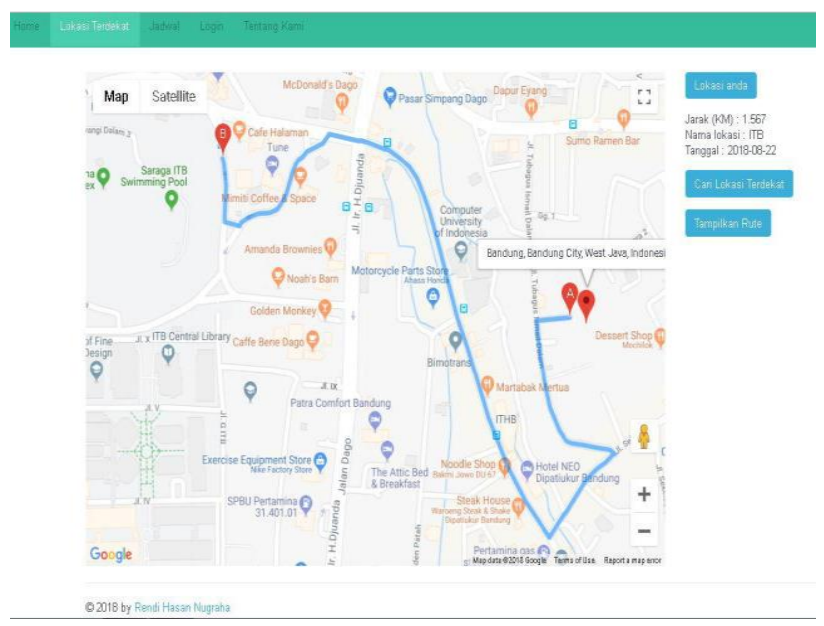

Gambar 8. Tampilan rute menuju lokasi kegiatan donor darah

Untuk mengimplementasikan sisitem ini, maka spesifikasi perangkat keras yang digunakan adalah sebagai berikut:

1. Processor Intel Pentium $1.2 \mathrm{GHz} @(2 \mathrm{CPUs})$

2. RAM 2GB

3. Harddisk $320 \mathrm{~GB}$

4. VQA Card $761 \mathrm{MB}$

Sedangkan untuk spesifikasi perangkat lunak yang digunakan dalam merancang sistem ini adalah sebagai berikut:

1. Sistem operasi windows 7

2. Web browser Google Chrome

3. Menggunakan server local yang merupakan paket dari XAMPP

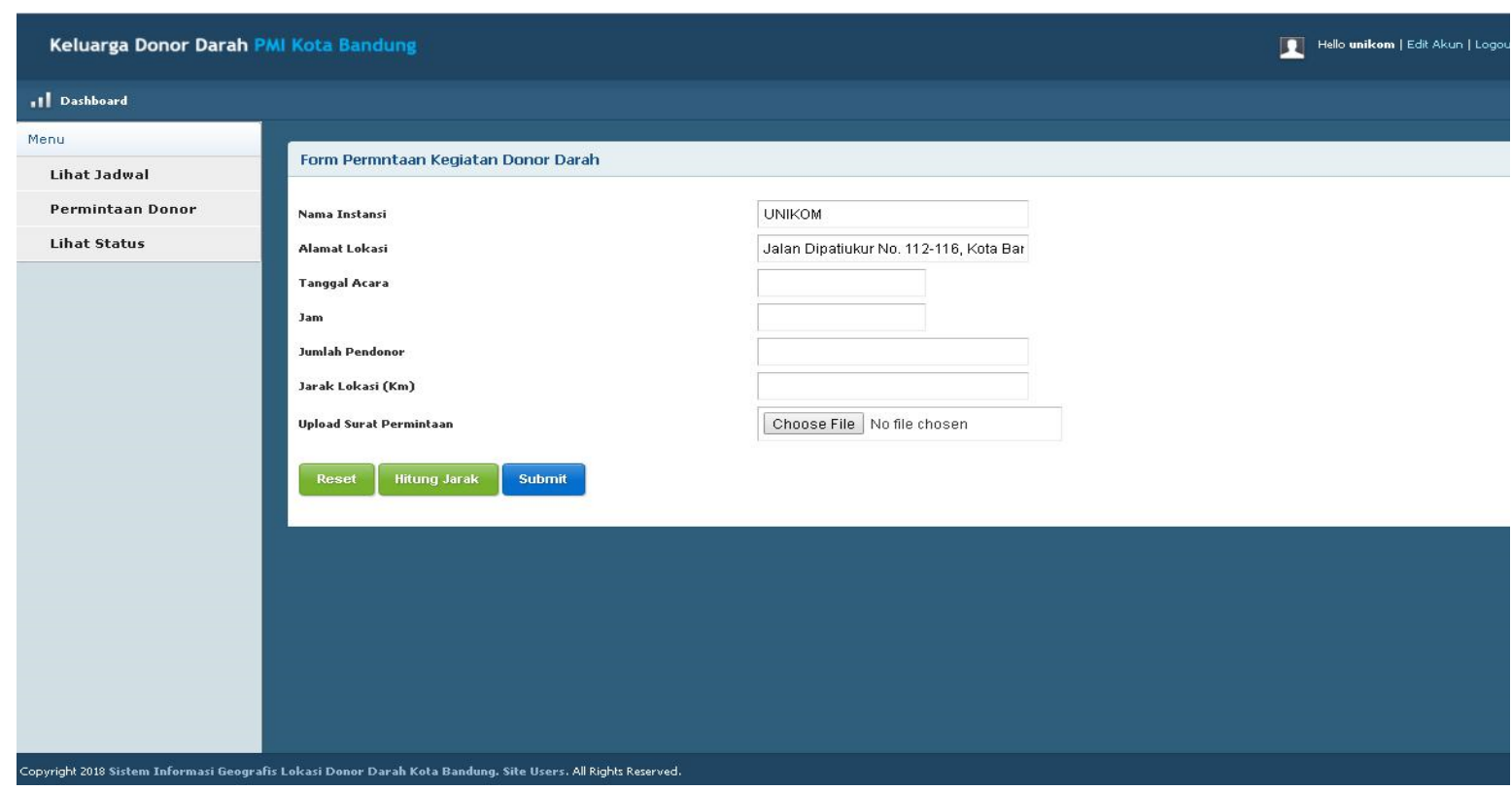

Gambar 9. Tampilan permintaan kegiatan donor darah 


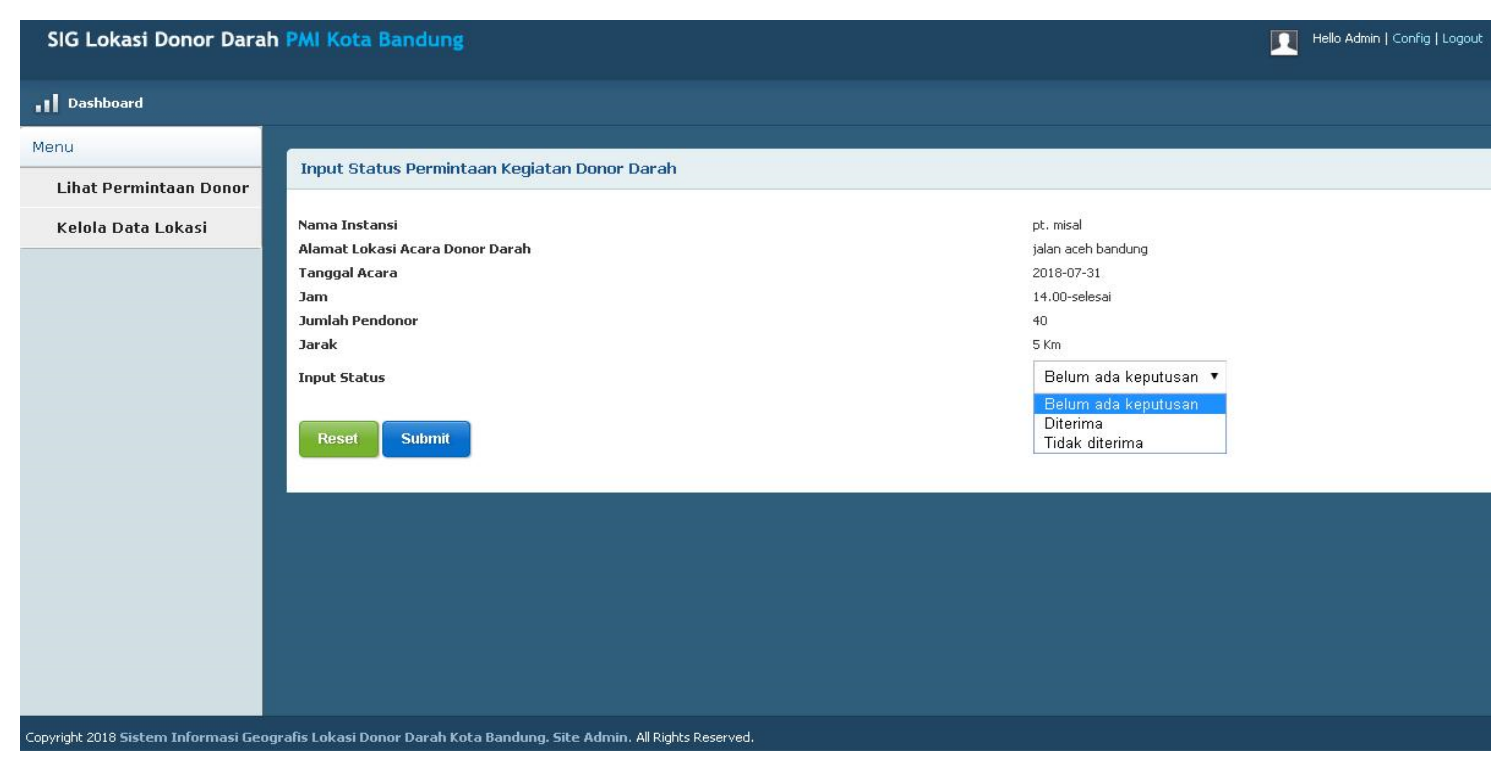

Gambar 10. Tampilan input status permintaan kegiatan donor darah

Untuk melihat apakah system yang dibangun memenuhi tujuan yang akan dicapai, maka dilakukkan pengujian terhadap system. Pengujian dilakukan dengan dua cara yaitu pengujian alpha dan pengujian betha.

Metode yang digunakan untuk pengujian alpha adalah metode Blackbox. Pengujian black box adalah pengujian yang mendemonstrasikan fungsi dari perangkat lunak yang beroperasi, dengan mengecek apakah data masukan sudah bisa diterima dengan baik, dan hasil keluarannya sesuai dengan apa yang diharapkan [10] . Daftar item yang di uji dapat dilihat pada tabel 6. Dari hasil pengujian sistem yang telah dilakukan, secara fungsional sistem sudah dapat digunakan dan menghasilkan keluaran yang diharapkan.

Pengujian beta dilakukan dengan tujuan untuk mengetahui apakah system yang dibuat sudah memenhui kebutuhan pengguna dan apakah sudah sesuai dengan harapan atau belum. Pengujian beta dilakukan dengan cara melakukan wawancara dan kuisioner terhadap pengguna aplikasi. Dari hasil pengujian beta, didapat bahwa system sudah dapat memberikan informasi lokasi kegiatan donor darah, lokasi donor darah terdekat, dan rute menuju ke lokasi tersebut, serat system sudah dapat membantu pihak PMI Kota Bandung dalam memberikan informasi lokasi kegiatan donor darah, dan proses penerimaan permintaan kegiatan donor darah.
Tabel 6. Skenario Pengujian

\begin{tabular}{|c|c|c|}
\hline No & Item Uji & Skenario Pengujian \\
\hline 1 & $\begin{array}{l}\text { Lihat lokasi donor } \\
\text { darah }\end{array}$ & $\begin{array}{l}\text { Menampilkan titik - titik } \\
\text { lokasi donor darah }\end{array}$ \\
\hline 2 & $\begin{array}{l}\text { Lihat } \\
\text { kegiatan } \\
\text { darah }\end{array}$ & $\begin{array}{l}\text { Menampilkan jadwal } \\
\text { kegiatan donor darah }\end{array}$ \\
\hline \multirow[t]{2}{*}{3} & \multirow{2}{*}{$\begin{array}{l}\text { Pencarian } \\
\text { donor } \\
\text { terdekat }\end{array}$} & Menampilkan lokasi user \\
\hline & & $\begin{array}{l}\text { Menampilkan lokasi donor } \\
\text { darah terdekat }\end{array}$ \\
\hline 4 & Menampilkan rute & $\begin{array}{l}\text { Menampilkan rute menuju } \\
\text { lokasi donor darah }\end{array}$ \\
\hline 5 & Daftar akun & $\begin{array}{l}\text { Pendaftaran akun untuk } \\
\text { instansi }\end{array}$ \\
\hline 6 & Login & $\begin{array}{l}\text { Masuk ke halaman utama } \\
\text { untuk isntansi dan admin }\end{array}$ \\
\hline 7 & $\begin{array}{ll}\text { Lihat jadwal } \\
\text { permintaan }\end{array}$ & $\begin{array}{l}\text { Menampilkan jadwal } \\
\text { permintaan kegiatan donor } \\
\text { darah }\end{array}$ \\
\hline 8 & $\begin{array}{l}\text { Periksa } \\
\text { ketersediaan jadwal }\end{array}$ & Cek ketersediaan jadwal \\
\hline 9 & $\begin{array}{l}\text { Permintaan } \\
\text { kegiatan } \\
\text { darah }\end{array}$ & $\begin{array}{l}\text { Pengajuan permintaan } \\
\text { kegiatan donor darah }\end{array}$ \\
\hline 10 & $\begin{array}{l}\text { Lihat } \\
\text { permintaan }\end{array}$ & $\begin{array}{l}\text { Melihat status permintaan } \\
\text { kegiatan donor darah }\end{array}$ \\
\hline 11 & $\begin{array}{l}\text { Lihat permintaan } \\
\text { kegiatan donor } \\
\text { darah }\end{array}$ & $\begin{array}{l}\text { Menampilkan permintaan } \\
\text { donor darah }\end{array}$ \\
\hline 12 & $\begin{array}{ll}\text { Input } & \text { status } \\
\text { permintaan } & \text { donor } \\
\text { darah } & \\
\end{array}$ & $\begin{array}{l}\text { Input status permintaan } \\
\text { donor darah }\end{array}$ \\
\hline \multirow[t]{3}{*}{13} & \multirow[t]{3}{*}{ Kelola data lokasi } & Tambah data lokasi \\
\hline & & Edit data lokasi \\
\hline & & Hapus data lokasi \\
\hline
\end{tabular}




\section{KESIMPULAN}

Berdasarkan hasil pengujian yang telah dilakukkan maka dapat ditarik kesimpulan bahwa secara fungsional sistem pencarian lokasi donor sistem sudah dapat digunakan dan menghasilkan keluaran yang diharapkan. System sudah meberikan informasi lokasi terdekat untuk kegiatan donor darah beserta informasi rute untuk menuju ke lokasi tersebut. System juga sudah dapat digunakan untuk permintaan instansi untuk mengadakan kegiatan donor darah. Selain itu berdasarkan hasil pengujian terhadap pengguna system, $83,66 \%$ pengguna setuju jika dapat memberikan informasi data tentang lokasi donor darah terdekat beserta rute untuk menuju lokasi tersebut, dan membantu Palang Merah Indonesia (PMI) dalam memberikan informasi lokasi donor darah, jadwal donor darah dan proses penerimaan permintaan untuk kegiatan donor.

\section{UCAPAN TERIMA KASIH}

Penulis berterima kasih kepada Universitas Komputer Indonesia dan PMI Kota Bandung atas dukungan dalam menyelesaikan penelitian ini.

\section{DAFTAR PUSTAKA}

[1] A. Makiyah, "Analisis persepsi masyarakat terhadap pentingnya pengetahuan donor darah bagi kesehatan," J. Ilm. Kesehat. dan Keperawatan, pp. 29-34, 2016.

[2] S. Farahdina, "Donor Darah dan Profil Lipid," J Major., 2015.

[3] A. Field, R. C. Mayer, and J. H. Davis, "The Effect of the Performance Appraisal System on Trust for Management :," Appl. Psychol., 1999.

[4] L. Ummu and R. A. Triyono, "Rancang Bangun Sistem Informasi Manajemen Pendonoran Darah Pada Udd Pmi Kabupaten Pacitan," Indones. J. Comput. Sci., vol. 10, no. 2, pp. 48-56, 2013.

[5] M. Burrakhman et al., "Rancang Bangun Sistem Informasi Donor Darah Berbasis Web (Studi Kasus: Unit Kegiatan Mahasiswa Korps Sukarela Universitas Mulawarman)," J. Inform. Mulawarman, vol. 11, no. 1, 2016.

[6] C. A. Sugiatno and T. M. Zundi, "Rancang Bangun Aplikasi Donor Darah Berbasis Mobile di PMI Kabupaten Bandung," J. Ilm. Manaj. Inform. dan Komput., vol. 01, no. 01, pp. 11-18, 2017.

[7] R. Susanto and A. D. A. Andriana, "Perbandingan Model Waterfall Dan Prototyping untuk Pengembangan Sistem Informasi," Maj. Unikom, 2016.

[8] M. S. Amri, "Membangun Sistem Navigasi Di Surabaya Menggunakan Google Maps Api,"
2011.

[9] J. H.M, Analisis dan Desain ( Sistem Informasi Pendekatan Terstruktur Teori dan Praktek Aplikasi Bisnis ). Penerbit Andi, 2017.

[10] M. S. Mustaqbal, R. F. Firdaus, and H. Rahmadi, "Pengujian Aplikasi Menggunakan Black Box Testing Boundary Value Analysis," Penguji. Apl. Menggunakan Black Box Test. Bound. Value Anal. (Studi Kasus Apl. Prediksi Kelulusan SNMPTN), vol. I, no. 3, p. 34, 2015. 